A Laboratory Study on

Revegetation and Metal Uptake in

Native Plant Species from Neutral

Mine Tailings

Journal Article

Author(s):

Conesa Alcaraz, Héctor M.; Schulin, R.; Nowack, Bernd

Publication date:

2007

Permanent link:

https://doi.org/10.3929/ethz-b-000008371

Rights / license:

In Copyright - Non-Commercial Use Permitted

Originally published in:

Water, Air, \& Soil Pollution 183(1-4), https://doi.org/10.1007/s11270-007-9369-1 


\title{
A Laboratory Study on Revegetation and Metal Uptake in Native Plant Species from Neutral Mine Tailings
}

\author{
Héctor M. Conesa • Rainer Schulin • \\ Bernd Nowack
}

Received: 1 September 2006 / Accepted: 12 February 2007 / Published online: 9 March 2007

(C) Springer Science + Business Media B.V. 2007

\begin{abstract}
Lygeum spartum, Zygophyllum fabago and Piptatherum miliaceum are typical plant species that grow in mine tailings in semiarid Mediterranean areas. The aim of this work was to investigate metal uptake of these species growing on neutral mine tailings under controlled conditions and their response to fertilizer additions. A neutral mine tailing ( $\mathrm{pH}$ of soil solution of 7.1-7.2) with high total metal concentrations $\left(9,100\right.$ and 5,200 $\mathrm{mg} \mathrm{kg}^{-1} \mathrm{Zn}$ and $\mathrm{Pb}$, respectively) from Southern Spain was used. Soluble $\mathrm{Zn}$ and $\mathrm{Pb}$ were low $\left(0.5\right.$ and $<0.1 \mathrm{mg}^{-1}$, respectively) but the major cations and anions reached relatively high levels (e.g. 2,600 and 1,400 $\mathrm{mg} \mathrm{l}^{-1} \mathrm{Cl}$ and $\mathrm{Na}$ ). Fertilization caused a significant increase of the plant weight for the three species and decreased metal accumulation with the exception of $\mathrm{Cd}$. Roots accumulated much higher metal concentrations for the three plants than shoots, except $\mathrm{Cd}$ in L. spartum. Shoot concentrations for the three plants were 3$14 \mathrm{mg} \mathrm{kg}^{-1} \mathrm{Cd}, 150-300 \mathrm{mg} \mathrm{kg}^{-1} \mathrm{Zn}, 4-11 \mathrm{mg} \mathrm{kg}^{-1}$ $\mathrm{Cu}$, and $1-10 \mathrm{mg} \mathrm{kg}^{-1} \mathrm{As}$, and $6-110 \mathrm{mg} \mathrm{kg}^{-1} \mathrm{~Pb}$.
\end{abstract}

H. M. Conesa $(\triangle) \cdot$ R. Schulin $\cdot$ B. Nowack Institute of Terrestrial Ecosystems, ETH Zurich, Universitaetstrasse 16, 8092 Zurich, Switzerland e-mail: hector.conesa@env.ethz.ch

B. Nowack

Empa-Materials Science and Technology, Lerchenfeldstrasse 5, 9014 St. Gallen, Switzerland
The results indicate that neutral $\mathrm{pH}$ mine tailings present a suitable substrate for establishment of these native plants species and fertilizer favors this establishment. Metal accumulation in plants is relatively low despite high total soil concentrations.

Keywords Mine tailings · Semiarid climate · Zygophyllum fabago $\cdot$ Piptatherum miliaceum . Lygeum spartum $\cdot$ Phytoremediation

\section{Introduction}

Mining activities have deleterious effects on the environment due to the deposition of huge amounts of wastes in the form of mine tailings (Dudka and Adriano 1997). These tailings usually present unfavorable conditions for natural plant establishment such as low pH (Wong et al. 1998) toxic metal concentrations (Norland and Veith 1995; Wong et al. 1998; Ye et al. 2000), high salt content (Norland and Veith 1995; Wong et al. 1998), low water retention capacity (Henriques and Fernandes 1991; Norland and Veith 1995) and deficiencies in nutrients (Wong 2003). In most cases the tailings also have steep slopes that are unstable and prone to erosion (Henriques and Fernandes 1991).

Among all the techniques that can be used for in situ reclamation of mine wastes, revegetation is 
considered the most suitable for a long term reclamation (Tordoff et al. 2000). Vegetation can provide an effective protection against wind and water erosion (Norland and Veith 1995). The vegetation also may improve the nutrient conditions in the soil (Cobb et al. 2000) and can provide the basis for the establishment of a self-sustaining vegetative cover (Norland and Veith 1995).

For revegetation it is very useful to choose plants that have spontaneously colonized mining sites and that are well adapted to these polluted environments. In semiarid mining zones the establishment of vegetation also requires plant species adapted to drought. The naturally-occurring, metal tolerant vegetation that grows on and around mining zones in arid and semiarid regions has been studied extensively (Alvarenga et al. 2004; Álvarez-Rogel et al. 2004; Flores-Tavizón et al. 2003; García et al. 2003; Leita et al. 1989; Melendo et al. 2002). Tolerant plant species can spread easily in these environments because of lack of competitors (Macnair 1987).

Lygeum spartum L. (Family Poaceae), is a widespread grass in the Mediterranean zone that can tolerate extreme conditions of aridity, salinity and high temperatures (Diaz and Honrubia 1993). This species has been found on acid mine tailings ( $\mathrm{pH}<$ 5) from Southern Spain (Conesa et al. 2006) but did not colonize neutral mine tailings in the same zone.

Piptatherum miliaceum (L.) (Cosson or smilo grass, Family Poaceae) is another species that grows naturally in these polluted ecosystems (Melendo et al. 2002; García et al. 2003; Conesa et al. 2006). It is commonly found in pastures and open grassy places throughout the Mediterranean region and has been introduced worldwide (García et al. 2004a). Young plants are also eaten by cattle (Conesa 2005). Both, $L$. spartum and $P$. miliaceum, have a strong rhizomatic root system which facilitates a suitable fixation of the plant in the soil and reduces erosion (Conesa et al. 2003).

Zygophyllum fabago L. (Syrian beancaper), belonging to the Family Zygophyllaceae, is frequently found in the arid regions of Southern Europe and in the arid zones of the Mediterranean coast region (Tutin et al. 1968). It is considered an invasive plant species of crop lands (USDA 2005) that in extreme cases can dominate the vegetation excluding the native plant species (Davison and Wargo 2001). Conesa et al. (2006) and Melendo et al. (2002) have reported the presence of $Z$. fabago on mine tailings in Southern Spain. Conesa et al. (2003) reported good colonization and establishment of $Z$. fabago in the tailings. However, in spite of the high germination percentage, its subsequent establishment was not successful and few plants survived.

Some studies have evaluated metal uptake of P. miliaceum and Z. fabago in hydroponic culture (García et al. 2004a, b). Although these experiments allow for better control of growing conditions compared to soil experiments, they are not a realistic model of the natural conditions where the effect of soil buffering capacity influences compound availability to plants (Robinson et al. 1998).

The Cartagena-La Unión Mining District in Southeast Spain (Fig. 1) covers an area of $50 \mathrm{~km}^{2}$ and contains 48 acidic and neutral mine tailings (Ortega et al. 1993) with a surface of 160 ha (MartínezOrozco et al. 1993). Some previous studies in this zone have detected the presence of plant species that grow on mining wastes and show relative tolerance to high heavy metal concentrations (Álvarez-Rogel et al. 2004; García et al. 2003). Different types of vegetation colonize their surfaces (Conesa et al. 2006). Conesa et al. (2007) evaluated the response of $L$. spartum to calcite amendments and fertilizer application in acid mine tailing substrates, observing no effect of fertilizer addition and better growth with calcite addition.

Tailings with neutral $\mathrm{pH}$ seem to have less constraints to plant growth than acid tailings since the $\mathrm{pH}$ is more suitable for plant growth. Nevertheless, the deficiencies in nutrients, the phytotoxic metal concentrations, and high salt content may adversely affect plant establishment and growth.

The purpose of this work was to evaluate growth and metal uptake in L. spartum, P. miliaceum and $Z$. fabago growing in neutral mine tailing under controlled laboratory conditions and to investigate the response of these plant species to fertilizer additions. The results are then compared to previous hydroponic cultures or plants grown in the field. These plant species are very interesting for phytostabilization of mine tailings due to their adaptation to drought and fast spreading characteristics. 
Fig. 1 Location of the studied area
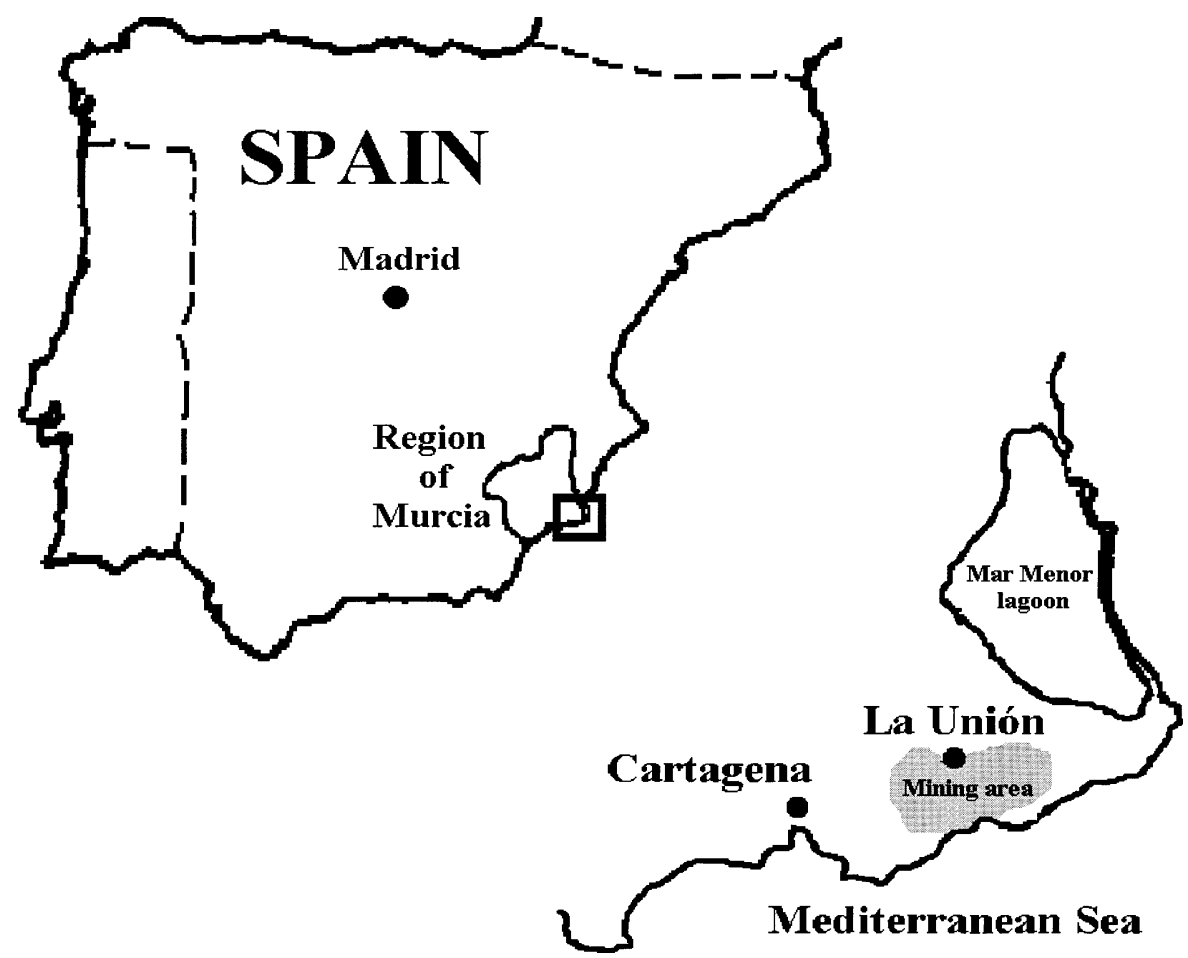

\section{Materials and Methods}

\subsection{Study Site}

The Cartagena-La Union Mining District (Fig. 1) constituted an important mining nucleus for more than 2,500 years, ceasing activity in 1991 . The terrain of this area is low lying ( $<400 \mathrm{~m}$ above sea level), but with steep slopes because of its proximity of the coast. The climate is typically Mediterranean with an annual rainfall around $250-300 \mathrm{~mm}$ concentrated during spring and autumn. The annual average temperature is $18^{\circ} \mathrm{C}$. Therefore, it can be regarded as a semiarid region.

The ore deposits of this zone have iron, lead and zinc, as the main metal components (Oen et al. 1975). As a consequence of the long period of mining activity, large volumes of wastes were generated during the mining and smelting processes (Conesa 2005; Martos-Miralles et al. 2001). Historically, these wastes were dumped into watercourses, filling riverbeds and contaminating their surroundings. In order to remedy this situation, the Government in 1955 prohibited mining companies from dumping wastes on the ground to form tailings (Vilar et al. 1991).

\subsection{Soil}

Soil samples from "El Gorguel" mine tailing -U.T.M. X 687480 m, Y 4162800 m, Z 135 m; length: 200300 m, width: $90-100 \mathrm{~m}$, height: $20-30 \mathrm{~m}$, volume: $750,000 \mathrm{~m}^{3}$ (IGME 1999)-, located on the "El Gorguel" dry river, were taken from the first $40 \mathrm{~cm}$ in different points homogenously distributed in the tailing. All soil samples were mixed (resulting in one homogenized sample per zone), air dried, sieved through $2 \mathrm{~mm}$ and stored in plastic bags. Total metal concentrations in mine tailing substrate used for this study have been reported in previous studies (Conesa 2005; Conesa et al. 2006) and are summarized in Table 1.

\subsection{Pot Experiment}

One kilogram of soil was placed into plastic pots (1 1 volume). For each of the three plant species (L. spartum, P. miliaceum and Z. fabago) a fertilized 
Table 1 Soil properties of "El Gorguel" tailing according to Conesa (2005) and Conesa et al. (2006): pH; Electrical Conductivity of the saturated extract (E.C.); Cation Exchange Capacity (C.E.C.); \% Organic Carbon (\%O.C.); \% Total Nitrogen; \% of clay, silt and sand; total and soluble metal concentrations

\begin{tabular}{|c|c|c|c|c|c|c|c|c|c|c|c|c|c|c|c|c|c|}
\hline \multirow[t]{3}{*}{$\mathrm{pH}$} & \multirow[t]{2}{*}{ E.C. } & \multirow[t]{2}{*}{ C.E.C. } & \multirow[t]{2}{*}{ O.C. } & \multirow[t]{2}{*}{ T.N. } & \multirow[t]{2}{*}{ clay } & \multirow[t]{2}{*}{ silt } & \multirow[t]{2}{*}{ sand } & \multicolumn{5}{|c|}{ Total metal content } & \multicolumn{5}{|c|}{ Soluble metal in $\mathrm{H}_{2} \mathrm{O}$} \\
\hline & & & & & & & & $\mathrm{Cu}$ & $\mathrm{Zn}$ & $\mathrm{Cd}$ & $\mathrm{Pb}$ & As & $\mathrm{Cu}$ & $\mathrm{Zn}$ & $\mathrm{Cd}$ & $\mathrm{Pb}$ & As \\
\hline & $\mathrm{dS} \mathrm{m} \mathrm{m}^{-1}$ & $\operatorname{cmol}(+) \mathrm{kg}^{-1}$ & & & $\%$ & & & & & $\mathrm{mg}$ & $\mathrm{kg}^{-1}$ & & & & $\mathrm{mg}$ & $g^{-1}$ & \\
\hline 7.2 & 8 & 9 & 0.4 & 0.018 & 5 & 22 & 73 & 84 & 9,100 & 34 & 5,200 & 350 & $<0.5$ & 2.3 & $<0.5$ & $<2.5$ & na \\
\hline
\end{tabular}

na: not available.

and a non-fertilized treatment with four repetitions was made. The soil was kept close to field capacity by adding $\sim 300 \mathrm{ml}$ water per week (every 2-3 days). The fertilizer $\left(80 \mathrm{~N}, 80 \mathrm{P}, 110 \mathrm{~K}, 25 \mathrm{Mg}\right.$ in $\mathrm{mg} \mathrm{kg}^{-1}$ soil) was added with the irrigation water: $30 \%$ were added in the first week, $20 \%$ in the second and $10 \%$ in each following week until $100 \%$ was reached. $\mathrm{KNO}_{3}$, $\mathrm{KH}_{2} \mathrm{PO}_{4}, \mathrm{NH}_{4} \mathrm{NO}_{3}$, and $\mathrm{Mg}\left(\mathrm{NO}_{3}\right)_{2} \cdot 6 \mathrm{H}_{2} \mathrm{O}$ were used as chemicals. The plants were grown from seeds that were taken directly from the "El Gorguel" tailing, where they naturally grow. Seeds were pregerminated in Petri dishes with wet filter paper with Millipore water. Germination in Petri dishes was around $70 \%$ for Z. fabago and $50 \%$ for L. spartum after 7 days while it was $30 \%$ for $P$. miliaceum after 14 days. Seedlings were maintained in small pots with the tailing substrate during one week. Afterwards, two healthy plants of Z. fabago and one of P. milicaeum and $L$. spartum were planted in each pot. The plants were grown in a climate chamber for 8 weeks with a light cycle of $16 \mathrm{~h}$ light- $8 \mathrm{~h}$ darkness and controlled humidity $(50-90 \%)$ and temperature $\left(16 / 23^{\circ} \mathrm{C}\right.$ night/ day).

\subsection{Soil Solution Samples}

Samples of soil solution were taken from eight pots of each treatment (fertilizer/no fertilizer) using Rhizon Flex soil moisture samplers (Rhizosphere Research Products, Wageningen, The Netherlands) which were installed at an angle of $45^{\circ}$ in each pot. Soil solution samples were taken at the middle of the experiment (fourth week after planting) and stored in plastic tubes at $5^{\circ} \mathrm{C}$. The following analyses were made: $\mathrm{pH}$ using a $691 \mathrm{pH}$ Meter (Metrohm); electrical conductivity using a conductivity meter WTW LF318/SET; anions using an IC20 Ion Chromatograph (Dionex); and cations using ICP-OES (Vista-MPX Varian) for $\mathrm{Pb}$,
$\mathrm{Cu}, \mathrm{Cd}, \mathrm{Zn}$ and As and Flame AAS (SpectraAA 220/ $\mathrm{FS}$, Varian) for $\mathrm{Ca}, \mathrm{Mg}, \mathrm{Na}$ and $\mathrm{K}$.

\subsection{Plant Analyses}

The plants were harvested in the eighth week of the experiment, washed with deionised water, and dried at $65^{\circ} \mathrm{C}$. Shoots and roots were separated prior to grinding (RETSCH Schieritz und Hauenstein AG). The dry weight of plants was obtained for individual plants. For the metal content analyses from Z. fabago we obtained one representative sample per pot by combining the individual plants. These samples were digested with $2 \mathrm{ml} \mathrm{H}_{2} \mathrm{O}_{2}$ (30\%), $5 \mathrm{ml} \mathrm{HNO}_{3}$ (65\%) and $2 \mathrm{ml} \mathrm{H}_{2} \mathrm{O}$ using microwaves (MLS-1200 MEGA ETHOS). Afterwards, the solution was diluted using Milipore water to $25 \mathrm{ml}$. $\mathrm{Cu}, \mathrm{Zn}, \mathrm{As}, \mathrm{Pb}$ and $\mathrm{Cd}$ were measured by ICP-OES (Vista-MPX Varian). Quality control was carried out using the Certified Reference Material of the Community Bureau of Reference BCR No 62 (Olea europaea).

All Statistical analyses (ANOVA and LSD test) were carried out with Systat 10.2 (SYSTAT 2002). Differences at $P<0.05$ level were considered significant.

\section{Results}

\subsection{Soil Solution}

The soil solution $\mathrm{pH}$ was 7.1 for the unamended sample and dissolved $\mathrm{Cu}, \mathrm{Cd}, \mathrm{Pb}$ and $\mathrm{As}$ were below the detection limit of $0.1 \mathrm{mg} \mathrm{l}^{-1}$ (Table 2). Dissolved $\mathrm{Zn}$ was $0.47 \mathrm{mg} \mathrm{l}^{-1}$. The salt concentrations were very high with sulfate, chloride, $\mathrm{Na}$ and $\mathrm{Ca}$ being the most important anions and cations.

Sulfate concentration exceeded $1,440 \mathrm{mg}^{-1}$ (30 meq $1^{-1}$ ), which Alarcón-Vera (2004) considered 
Table 2 Soil solution concentrations of anions and cations in $\mathrm{mg} \mathrm{l}^{-1}$
Values in brackets are standard deviation. Different letters indicate significant differences $(P<0.05)$.

\begin{tabular}{llll}
\hline Parameter & & No fertilizer $n=8$ & Fertilizer $n=8$ \\
\hline $\mathrm{pH}$ & & $7.1(<0.1) \mathrm{a}$ & $7.2(0.2) \mathrm{a}$ \\
E.C. $\left(\mathrm{dS} \mathrm{m}^{-1}\right)$ & $\mathrm{Na}$ & $11(2.7) \mathrm{a}$ & $14(4.1) \mathrm{a}$ \\
Metals & $\mathrm{Mg}$ & $850(220) \mathrm{a}$ & $2,000(760) \mathrm{a}$ \\
& $\mathrm{K}$ & $38(6) \mathrm{a}$ & $1,200(460) \mathrm{a}$ \\
& $\mathrm{Ca}$ & $520(67) \mathrm{a}$ & $110(9) \mathrm{b}$ \\
& $\mathrm{Cu}$ & $<0.1$ & $500(71) \mathrm{a}$ \\
& $\mathrm{Zn}$ & $0.47(0.06) \mathrm{a}$ & $<0.1$ \\
& $\mathrm{Cd}$ & $<0.1$ & $0.55(0.09) \mathrm{b}$ \\
& $\mathrm{Pb}$ & $<0.1$ & $<0.1$ \\
& $\mathrm{As}$ & $<0.1$ & $<0.1$ \\
Metalloid & $\mathrm{Cl}-$ & $2,600(1,500) \mathrm{a}$ & $<0.1$ \\
Anions & $\mathrm{SO}{ }^{2-}$ & $4,900(2,100) \mathrm{a}$ & $3,900(2,100) \mathrm{a}$ \\
& & & $6,200(3,000) \mathrm{a}$ \\
\hline
\end{tabular}

The fertilizer application had a significant effect on $\mathrm{K}$ concentration while for all other major cations and anions the concentrations differences were not significant compared to treatments without fertilizer (Table 2). Dissolved Zn was slightly higher.

\subsection{Plant Growth}

The three plant species had a satisfactory growth in all the pots even though the growth pattern of each species was different. While Z. fabago showed fast growth, L. spartum and $P$. miliaceum grew more slowly. The plants without fertilizer showed less
Fig. 2 Dry weight of the plants from fertilized (white columns) and unfertilized (grey columns) treatments. Bars on columns are standard deviation, $n=4$ for $L$. spartum and $P$. miliaceum and $n=8$ for $Z$. fabago. Stars above columns indicate that fertilization caused a significant increase of the weight

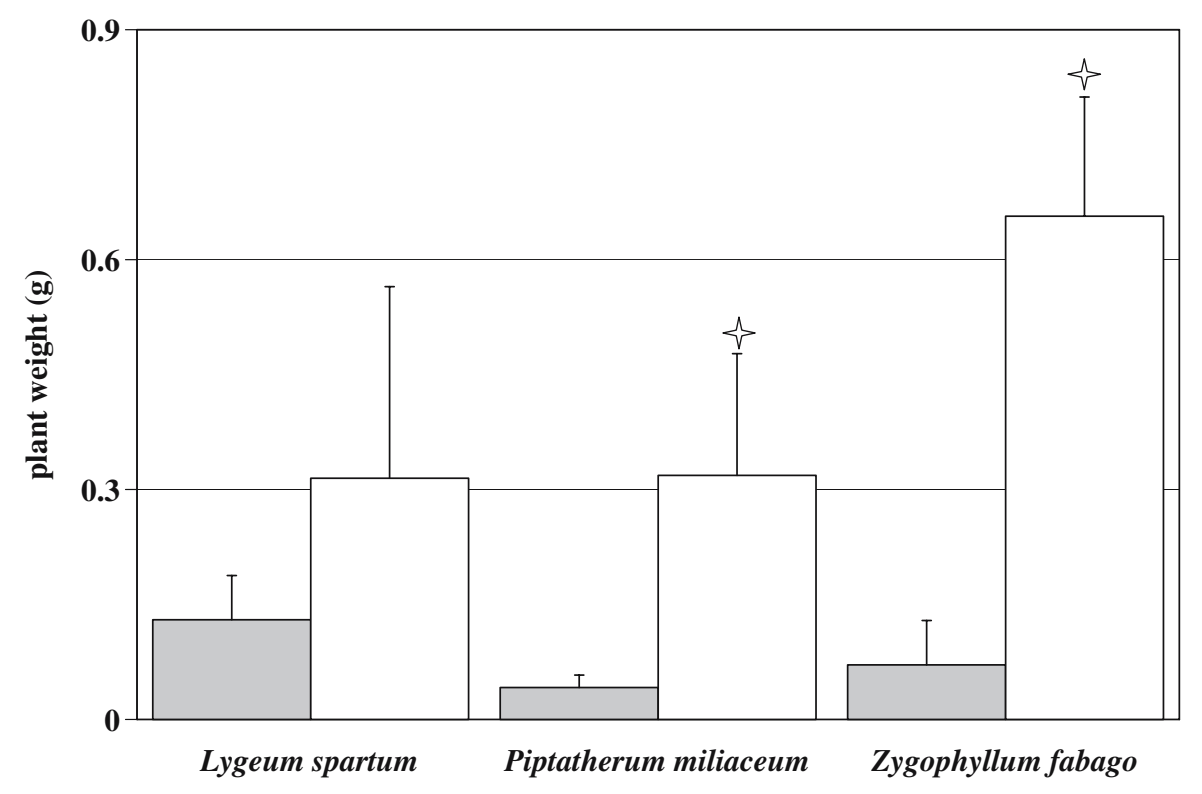


Fig. 3 Evolution in number of green leaves (total leaves minus chlorotic ones) per plant of Z. fabago (Zf) and L. spartum (Ls)

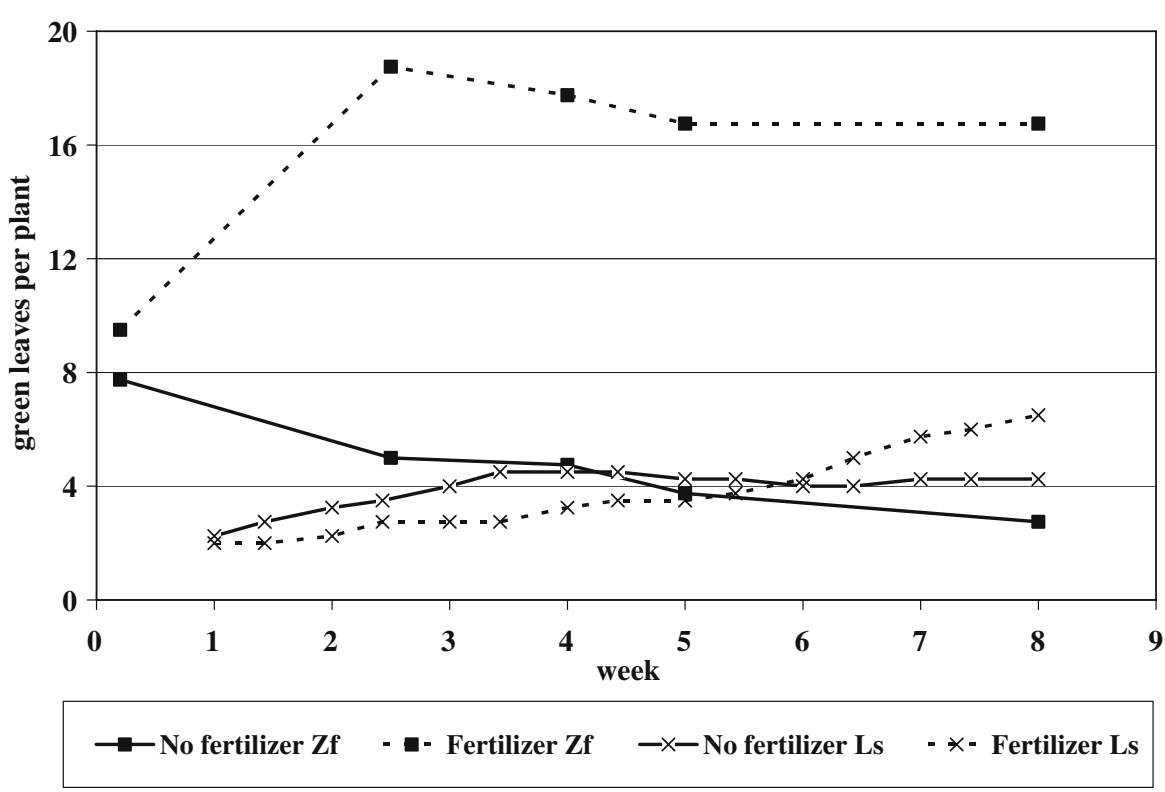

growth than the fertilized ones, although in the case of P. miliaceum this higher growth resulted in weak plants (vigour) and some stalks fell down.

For $P$. miliaceum and $Z$. fabago the fertilizer addition caused a significant increase $(P<0.05)$ in plant weight in the fertilizer treated pots (Fig. 2). In the treatment with fertilizer addition, Z. fabago had about 10 times more dry weight than without fertilizer (Fig. 2). Moreover, the Z. fabago plants with fertilizer addition produced 4-7 times more green leaves (total leaves minus chlorotic ones) after two weeks of the experiment (Fig. 3). However, the effect of fertilizer in increasing the weight was not seen for $L$. spartum $(P>0.05)$. For this species there was also no large difference in the number of leaves between fertilized and non-fertilized pots even though a tendency for higher number of leaves could be seen in the fertilized ones (Fig. 3).
Fig. $4 \mathrm{Cu}$ accumulation in roots (filled columns) and shoots (white columns) for the different treatments in the three plant species studied. Bars on columns are standard deviation $(n=4)$. Different letters indicate significant differences $(P<0.05)$

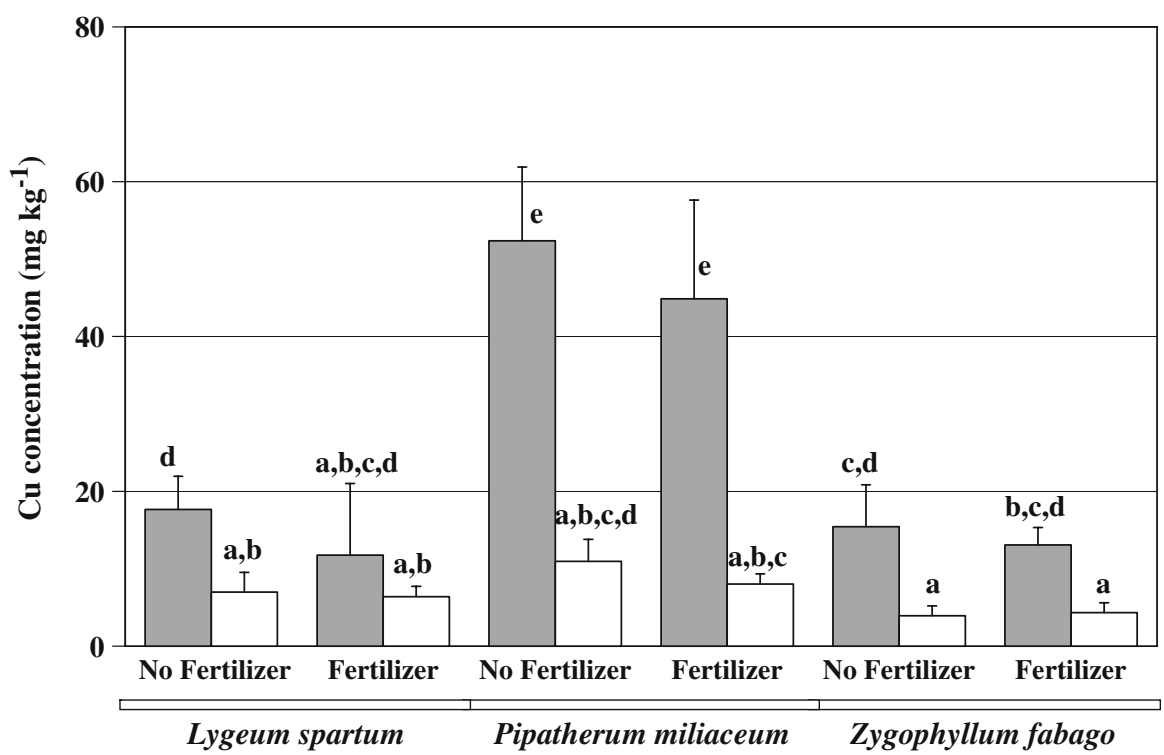


Fig. $5 \mathrm{Zn}$ accumulation in roots (filled columns) and shoots (white columns) for the different treatments in the three plant species studied. Bars on columns are standard deviation $(n=4)$. Different letters indicate significant differences $(P<0.05)$

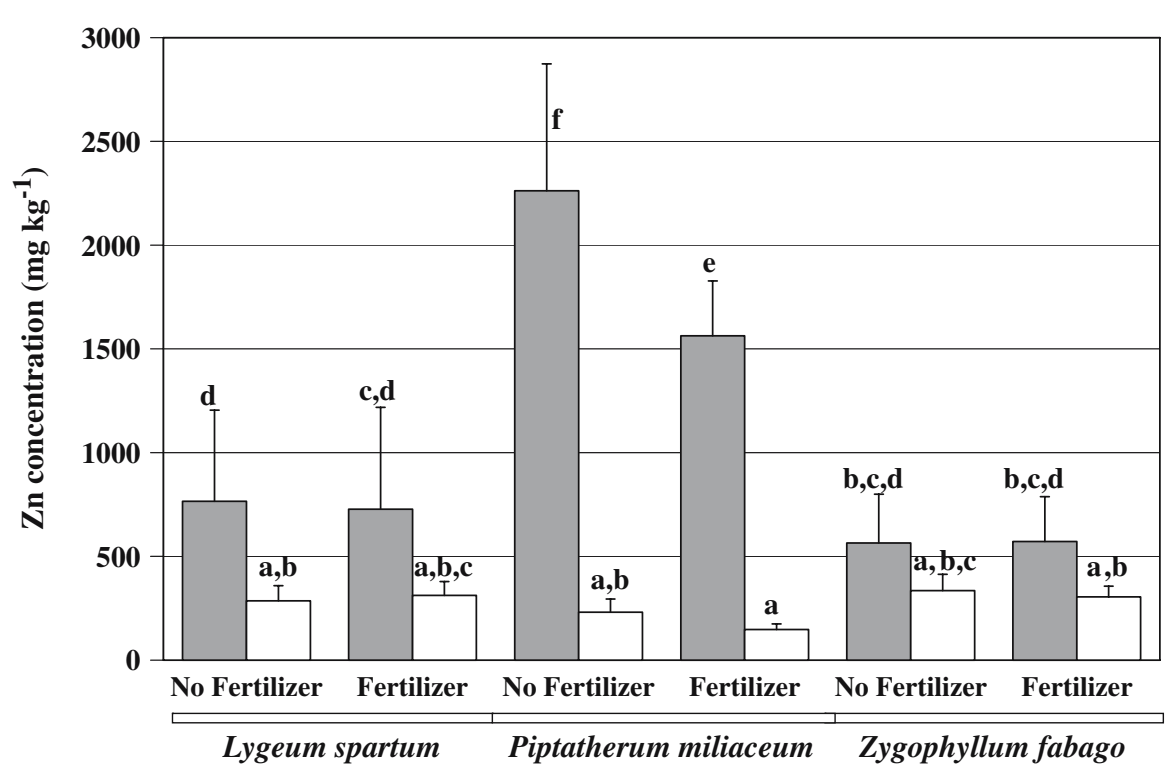

\subsection{Metal Uptake}

\subsubsection{Zygophyllum Fabago}

The fertilizer addition caused no statistically significant effect $(P>0.05)$ on metal uptake in shoots (Figs. 4, 5, 6, 7 and 8). At both treatments the $\mathrm{Cu}$ concentration was around $4 \mathrm{mg} \mathrm{kg}^{-1}$, Zn 300-330 mg $\mathrm{kg}^{-1}$ and $\mathrm{Cd} 7 \mathrm{mg} \mathrm{kg}^{-1}$. On the other hand, the fertilizer addition generated a decrease of the As and $\mathrm{Pb}$ concentration although these differences were not significant $(P>0.05)$ (Figs. 7 and 8$)$.
All the plants of Z. fabago showed higher metal concentration in roots compared to shoots although these difference were only significant $(P<0.05)$ for $\mathrm{Cu}$ and $\mathrm{Cd}$ (Figs. 4 and 6 respectively). The highest values were reached for $\mathrm{Zn}$ with concentrations around $500-600 \mathrm{mg} \mathrm{kg}^{-1}$. There was no strong effect of the fertilizer addition on $\mathrm{Zn}\left(560-570 \mathrm{mg} \mathrm{kg}^{-1}\right)$ and $\mathrm{Cu}$ $\left(15-13 \mathrm{mg} \mathrm{kg}^{-1}\right)$ concentration in the roots. However, the $\mathrm{Cd}$ concentration in roots increased by $50 \%$ (from 78 to $122 \mathrm{mg} \mathrm{kg}^{-1}$ ) and this increase was statistically significant $(P<0.05)$. On the other hand, the fertilizer addition generated a decrease of the $\mathrm{As}$ and $\mathrm{Pb}$
Fig. $6 \mathrm{Cd}$ accumulation in roots (filled columns) and shoots (white columns) for the different treatments in the three plant species studied. Bars on columns are standard deviation $(n=4)$. Different letters indicate significant differences $(P<0.05)$

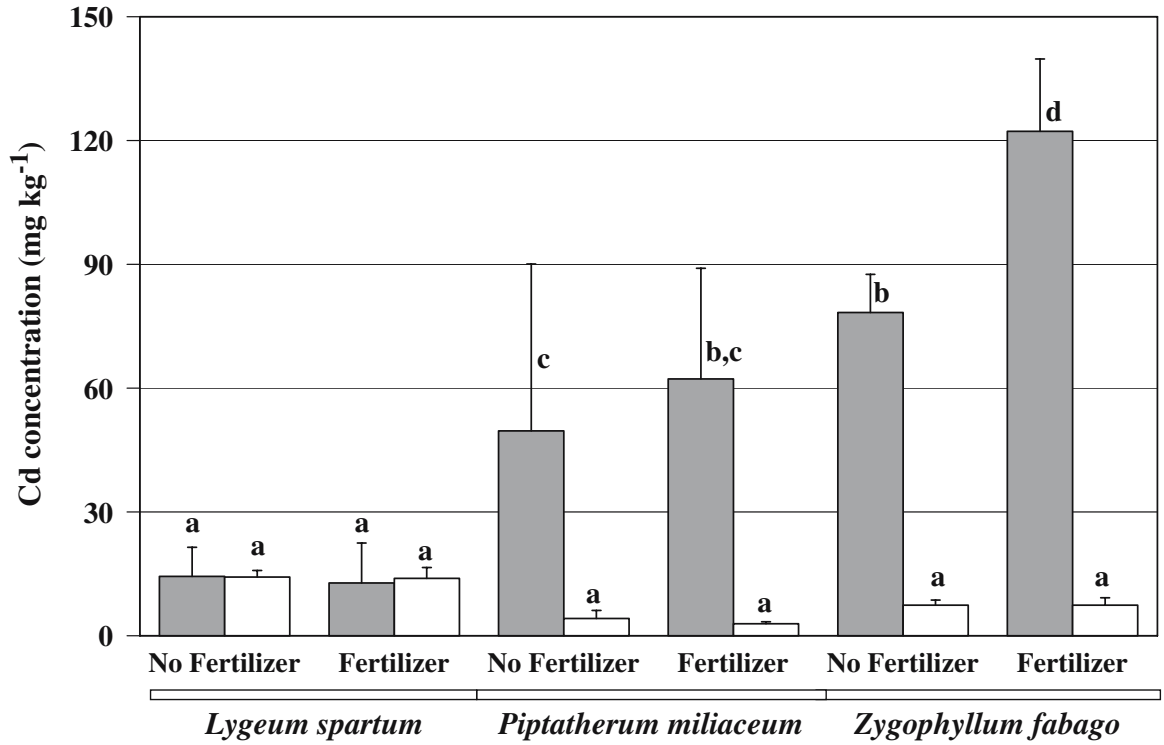


Fig. 7 As accumulation in roots (filled columns) and shoots (white columns) for the different treatments the three plant species studied. Bars on columns are standard deviation $(n=4)$. Different letters indicate significant differences $(P<0.05)$

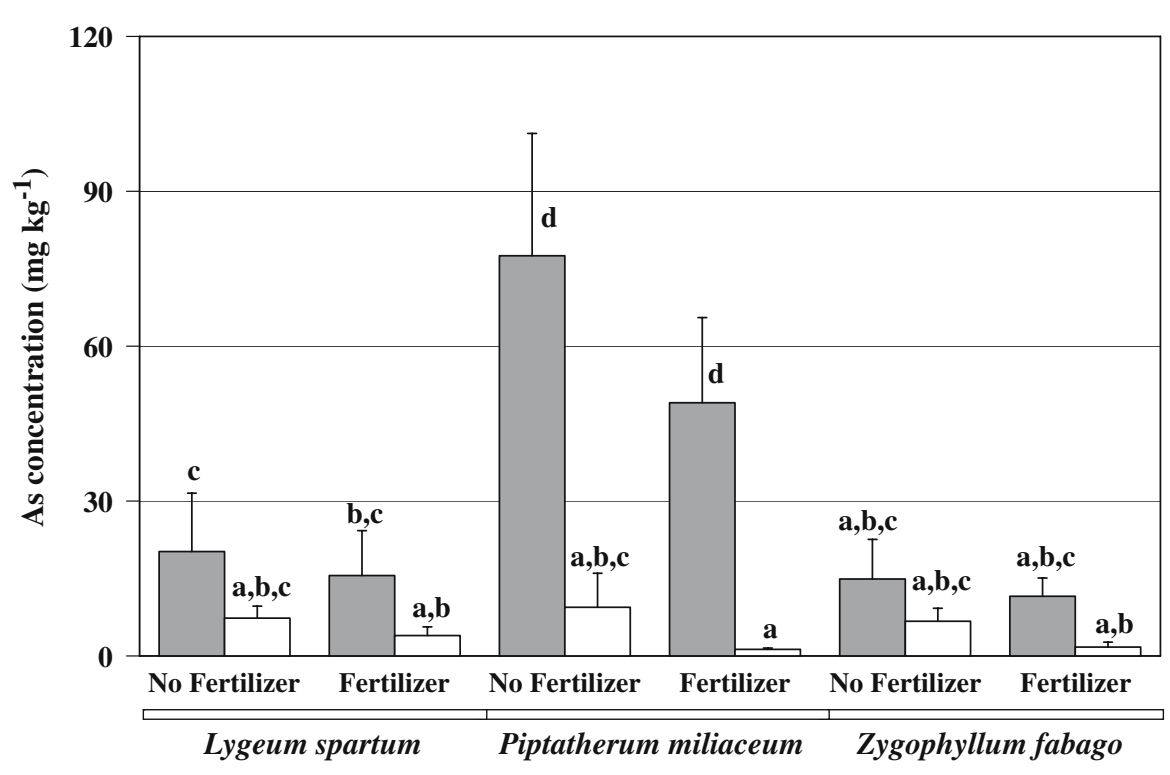

concentration (Figs. 7 and 8) with a smaller decrease for roots $(25-35 \%)$ compared to the shoots $(75-80 \%)$.

\subsubsection{Lygeum Spartum}

The fertilizer addition caused no significant differences $(P>0.05)$ of metal uptake even though in the fertilized pots the metal concentration was slightly lower. Shoot metal concentrations were lower than root concentrations except for $\mathrm{Cd}$ which had similar concentrations for both (14 $\mathrm{mg} \mathrm{kg}^{-1}$ ) (Fig. 6). Metal uptake in $L$. spartum reached similar values for shoots and roots for $\mathrm{Pb}, \mathrm{As}, \mathrm{Cu}$ and $\mathrm{Zn}$, in relation to $Z$. fabago. However there were significant differences $(P<0.05)$ between these two plant species for $\mathrm{Cd}$ content in roots.

All the metal concentrations in $L$. spartum roots were much lower and statistically different $(P<0.05)$ from $P$. miliaceum. However these differences did not occur for shoots $(P>0.05)$.
Fig. $8 \mathrm{~Pb}$ accumulation in roots (filled columns) and shoots (white columns) for the different treatments in the three plant species studied. Bars on columns are standard deviation $(n=4)$. Different letters indicate significant differences $(P<0.05)$

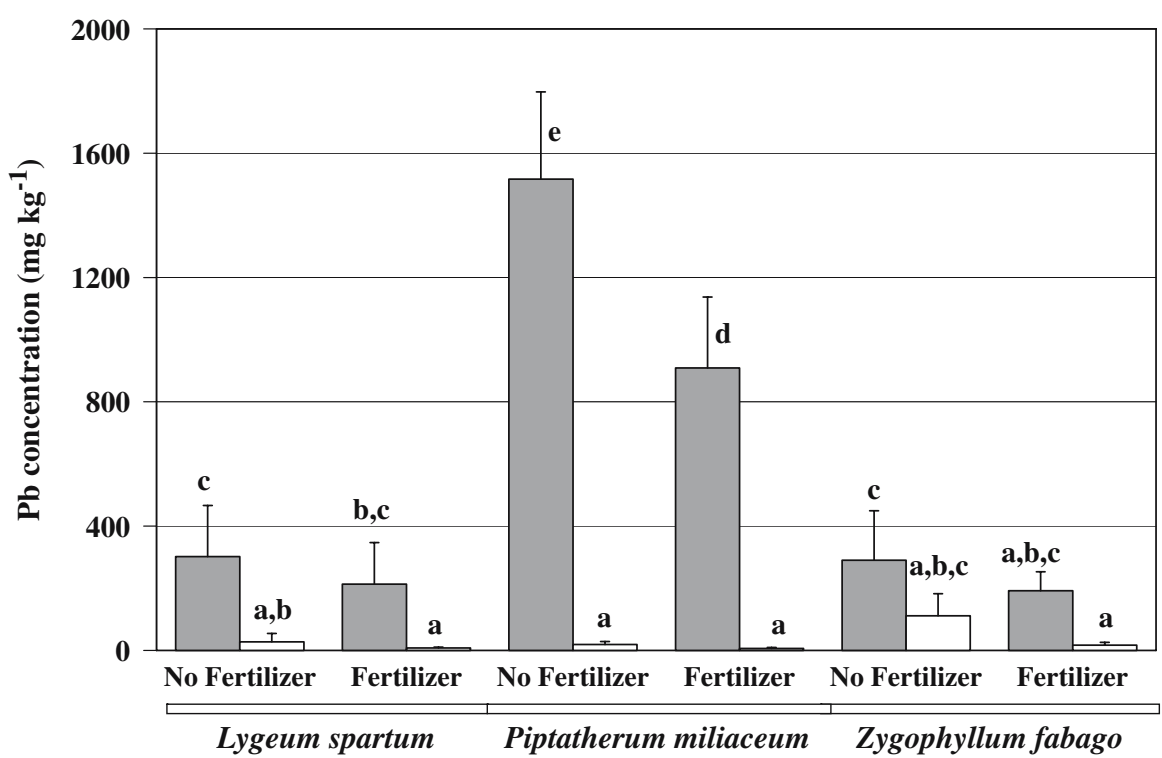




\subsubsection{Piptatherum Miliaceum}

P. miliaceum accumulated more $\mathrm{As}, \mathrm{Cu}, \mathrm{Zn}$ and $\mathrm{Pb}$ and less $\mathrm{Cd}$ in the roots than Z. fabago (Figs. 4, 5, 6, 7 and 8). Fertilizer addition had a similar effect than in $Z$. fabago and L. spartum and the metal concentrations were generally lower, except for $\mathrm{Cd}$. $\mathrm{Zn}$ reached the maximum value of all the plants and treatments in the control soil with root concentrations of around $2,000 \mathrm{mg} \mathrm{kg}^{-1}$. The maximum $\mathrm{Pb}$ root concentration was reached in the control soil too, with about $1,500 \mathrm{mg}$ $\mathrm{kg}^{-1}$ (Fig. 8). P. miliaceum had five times more As (Fig. 7) in roots than Z. fabago and L. spartum.

Shoot concentrations of $P$. miliaceum were higher for $\mathrm{Cu}$, similar for $\mathrm{As}$ and lower for $\mathrm{Zn}, \mathrm{Cd}$ and $\mathrm{Pb}$ than for $Z$. fabago and L. spartum, although these differences were not statistically significant $(P>0.05)$. However, all the values of metal concentrations in roots of $P$. miliaceum were statistically different $(P<0.05)$ in relation to the other two plant species studied.

\section{Discussion}

\subsection{Plant Growth}

In "El Gorguel" soil high salinity and high total heavy metal concentrations seem to be the major constraints to facilitate plant growth. Anion concentrations in soil solution are very important to determine the soil quality since these compounds are not retained by surfaces and they are therefore fully available for the roots. Chloride is directly toxic due to its high mobility and transport to the physiologically most actives parts of the plant (AlarcónVera 2004). Sulfate has more a limiting action on plant $\mathrm{Ca}$ uptake than a direct toxic effect. It increases the uptake of $\mathrm{Na}$ and $\mathrm{K}$ and also contributes to the increase of the osmotic pressure (Alarcón-Vera 2004). The high levels of chloride and sulfate that $Z$. fabago, L. spartum and $P$. miliaceum tolerate without showing toxic effects make them salinity tolerant.

The fertilizer addition facilitated the establishment of the plants. Nevertheless, Z. fabago had better response to fertilizer than P. miliaceum and L. spartum. P. miliaceum formed weak stalks in the presence of fertilizer. Probably this was due to the high nitrogen content that may favor fast growth. However, the application of fertilizer with less nitrogen content might avoid this problem.
4.2 Metal Uptake

The plants that grew in the fertilized pots showed lower metal concentrations than in non-fertilized pots, probably because of the higher biomass and the phytodilution effect. The metal concentrations in the shoots observed for $Z$. fabago in the pot experiment are lower than the levels that Conesa et al. (2006) measured in wild exemplars of the same species growing at mine tailings in SE Spain (Table 3). The $\mathrm{Cu}$ and $\mathrm{Zn}$ concentrations of $P$. miliaceum measured in the field were similar to the levels observed in the laboratory experiment. For $\mathrm{Pb}$ more data with a larger variation are available for the field and most values are higher than the values found in the laboratory.

Root concentrations of $Z$. fabago measured in the field were generally much higher than the values obtained in the pot experiment but only few data are available from the field. Melendo et al. (2002) for example reported $\mathrm{Pb}$ levels in roots of $Z$. fabago of over $2,000 \mathrm{mg} \mathrm{kg}^{-1}$. With the exception of $\mathrm{Zn}$ in roots, concentrations reported in this study were lower than accumulation values for two plant species, Z. fabago and $P$. miliaceum in hydroponic experiments reported by García et al. (2004a, b).

The $\mathrm{Zn}$ and $\mathrm{Cu}$ concentrations in shoots of wild exemplars of $L$. spartum that grew in acid mine tailings from the same Cartagena-La Unión Mining District (Conesa et al. 2007) were approximately 50\% lower than in our pot experiment. However, the $\mathrm{Pb}$ content was 50\% higher. The metal accumulation in roots of $L$. spartum was higher in the pot experiment than in the field. However, under controlled conditions and acid tailing substrates the levels were higher than under the same conditions but with the neutral tailing substrates. Finally, when L. spartum was grown under controlled conditions in limed acid substrate the metal uptake was comparable to our study.

The differences in metal uptake between field and controlled conditions may be attributed to the different physiologic state of plants and the modification of the soil properties and climate parameters under controlled conditions (Conesa et al. 2007).

Shoots from plants of our experiment surpassed the concentrations that Barceló and Poschenrieder (1992) considered normal in shoots when plants grow in nonpolluted sites for $\mathrm{Cd}\left(0.05-0.7 \mathrm{mg} \mathrm{kg}^{-1}\right), \mathrm{Pb}(10 \mathrm{mg}$ $\left.\mathrm{kg}^{-1}\right)$ and $\mathrm{Zn}\left(25-150 \mathrm{mg} \mathrm{kg}^{-1}\right)$ but they are in the same range for $\mathrm{Cu}\left(5-20 \mathrm{mg} \mathrm{kg}^{-1} \mathrm{Cu}\right)$. In this way, a 
Table 3 Metal accumulation for Z. fabago and P. miliaceum in plants that grow in field in mining wastes and values of accumulation reached in hydroponic experiments with inert substrate in the bibliography

\begin{tabular}{|c|c|c|c|c|c|c|c|c|}
\hline \multirow[t]{2}{*}{ Plant species } & \multirow[t]{2}{*}{ Site } & \multicolumn{3}{|l|}{ Roots } & \multicolumn{3}{|c|}{ Shoots } & \multirow[t]{2}{*}{ Reference } \\
\hline & & $\mathrm{Cu}$ & $\mathrm{Zn}$ & $\mathrm{Pb}$ & $\mathrm{Cu}$ & $\mathrm{Zn}$ & $\mathrm{Pb}$ & \\
\hline \multirow{6}{*}{$\begin{array}{l}\text { Piptatherum } \\
\text { miliaceum }\end{array}$} & Laboratory, pot experiment & $42-55$ & $1,500-2,200$ & $900-1,500$ & $8-11$ & $150-230$ & $6-19$ & This study \\
\hline & $\begin{array}{l}\text { Laboratory, hydroponic } \\
\text { experiment }\end{array}$ & - & 1,711 & 6,260 & - & 2,098 & 1,919 & $\begin{array}{l}\text { García et } \\
\text { al. (2004a) }\end{array}$ \\
\hline & SE Spain, mine tailing & - & - & 1,121 & - & - & 129 & $\begin{array}{l}\text { Melendo et } \\
\text { al. (2002) }\end{array}$ \\
\hline & SE Spain, mining soil & - & - & 9,958 & - & - & 981 & $\begin{array}{l}\text { Melendo et } \\
\text { al. (2002) }\end{array}$ \\
\hline & $\begin{array}{l}\text { SE Spain, mine tailing } \\
\text { "El Gorguel" }\end{array}$ & - & - & - & 3 & 135 & 34 & $\begin{array}{l}\text { Conesa et } \\
\text { al. }(2006)\end{array}$ \\
\hline & $\begin{array}{l}\text { SE Spain, riverbed with } \\
\text { mining wastes }\end{array}$ & - & - & 800 & - & - & 160 & $\begin{array}{l}\text { García et } \\
\text { al. (2003) }\end{array}$ \\
\hline \multirow{5}{*}{$\begin{array}{l}\text { Zygophyllum } \\
\text { fabago }\end{array}$} & Laboratory, pot experiment & $13-15$ & $560-570$ & $190-290$ & $4-29$ & $300-430$ & $110-620$ & This study \\
\hline & $\begin{array}{l}\text { Laboratory, hydroponic } \\
\text { experiment }\end{array}$ & - & 1,500 & 2,500 & - & 3,300 & 1,100 & $\begin{array}{l}\text { García et } \\
\text { al. (2004b) }\end{array}$ \\
\hline & $\begin{array}{l}\text { SE Spain, mine tailing } \\
\text { "El Gorguel" }\end{array}$ & - & - & - & 6 & 406 & 108 & $\begin{array}{l}\text { Conesa et } \\
\text { al. }(2006)\end{array}$ \\
\hline & $\begin{array}{l}\text { SE Spain, mine tailing } \\
\text { "El Lirio" }\end{array}$ & - & - & - & 7 & 528 & 163 & $\begin{array}{l}\text { Conesa et } \\
\text { al. }(2006)\end{array}$ \\
\hline & SE Spain, mining soil & - & - & 2,241 & - & - & 50 & $\begin{array}{l}\text { Melendo et } \\
\text { al. (2002) }\end{array}$ \\
\hline \multirow{4}{*}{$\begin{array}{l}\text { Lygeum } \\
\text { spartum }\end{array}$} & Laboratory, pot experiment & $12-18$ & $730-765$ & $210-300$ & $6-7$ & $285-310$ & $2-27$ & This study \\
\hline & $\begin{array}{l}\text { Laboratory, pot experiment } \\
\text { with acid tailing substrate }\end{array}$ & 66 & $3,450-3,600$ & 175 & 40 & $4,200-4,400$ & 62 & $\begin{array}{l}\text { Conesa et } \\
\text { al. }(2007)\end{array}$ \\
\hline & $\begin{array}{l}\text { Laboratory, pot experiment } \\
\text { with limed tailing substrate }\end{array}$ & $16-22$ & $400-500$ & $180-270$ & 8 & 230 & $13-16$ & $\begin{array}{l}\text { Conesa et } \\
\text { al. }(2007)\end{array}$ \\
\hline & SE Spain acid tailing soil & 6 & 170 & 125 & 3 & 175 & 55 & $\begin{array}{l}\text { Conesa et } \\
\text { al. (2007) }\end{array}$ \\
\hline
\end{tabular}

Data are in $\mathrm{mg} \mathrm{kg}^{-1}$.

continuous ingestion of these plant species by cattle and wild fauna could cause problems for metal accumulation in the food chain, although more studies have to be done in relation to the bioavailability of the pollutants, since total metal concentrations may not reflect the real risk. However, due to the high total metal concentrations in the soil the site would need to be fenced and hence this food-chain transfer would be small.

\subsection{Bioconcentration and Accumulation Factor}

The bioconcentration factor (Mattina et al. 2003) for roots (ratio between metal concentration in roots and metal in soil) and for shoots (ratio between metal concentration in shoots and metal in soil) expresses the ability of the plants to accumulate metals from the soil. This factor was below 0.2 for all the metals except for $\mathrm{Cd}$ where it reached values between $0.2-0.8$ in shoots and $0.4-3.6$ in roots. Values below 0.2 are considered normal by McGrath and Zhao (2003) when plants are grown on polluted materials.

The accumulation factor (Fitz and Wenzel 2002), also called translocation factor (Mattina et al. 2003), is the ratio between the concentration of metals in shoots and roots, and defines the effectiveness of the plant to translocate the metals to the shoots. Tolerant plants have values less than 1 and hyperaccumulators higher than 1 . In our case all the accumulation factors were below 1 with exception of L. spartum and $\mathrm{Cd}$ that had values of 1 . This 
means that the three investigated plant species can be considered tolerant and therefore may be an interesting option to revegetate neutral $\mathrm{pH}$ tailings in semiarid regions. The three species are already adapted to semiarid conditions and integrated in the semiarid Mediterranean ecosystem. This avoids one of the problems that some phytoremediation programs generate because of the introduction of non-native plant species in the ecosystem (Wolfe and Bjornstad 2002). Therefore, the studied plants present a specific solution for a certain climate, soil and geographical location that may restrict their use in phytostabilization works to the Mediterranean area.

$Z$. fabago has also been investigated because of its allergenic properties (Belchí et al. 1997). It may be important to take into account this aspect if the soil to remediate is near urban zones and exposed to dominant winds.

\section{Conclusions}

Zygophyllum fabago exhibits a good adaptation to heavily polluted neutral mine tailings even when the salinity of the soil is high. The metal uptake into shoots is relatively small. Therefore, this plant can be considered an interesting option to revegetate neutral $\mathrm{pH}$ mine tailings. However, its allergenic properties may require that this species has to be used far from populations and not-exposed to dominant winds.

Piptatherum miliaceum is another species that may be used in order to revegetate neutral soils with high heavy metal concentrations in semiarid climates. Metal accumulation in roots is high but the transfer to shoots is restricted. This decreases the risk of metals entering into the food chain.

Lygeum spartum has a similar behavior than $P$. miliaceum but the metal uptake ranges are closer to $Z$. fabago.

Fertilizer addition can improve the establishment of these plant species in the early stages of their growth and therefore it can be considered a promising tool to get a successful revegetation of mine tailings with similar characteristics in semiarid zones.

Acknowledgements This work was supported by a Postdoctoral grant for Dr Héctor M. Conesa from the "Fundación Séneca" of the "Comunidad Autónoma de la Región de Murcia” (Spain). We also thank Anna Grünwald, René Saladin, Björn Studer and Lu Zhao for their technical assistance.

\section{References}

Alarcón-Vera, A. L. (2004). Diagnóstico Agrícola. Cartagena, Spain: Escuela Técnica Superior de Ingeniería Agronómica de Cartagena.

Alvarenga, P. M., Araújo, M. F., \& Silva, J. A. L. (2004). Elemental uptake and root-leaves transfer in Cistus ladanifer L. growing in a contaminated pyrite mining area (Aljustrel-Portugal). Water Air and Soil Pollution, 152, 81-96.

Álvarez-Rogel, J., Ramos-Aparicio, M. J., Delgado-Iniesta, M. J., \& Arnaldos-Lozano, R. (2004). Metals in soils and above-ground biomass of plants from a salt marsh polluted by mine wastes in the coast of the Mar Menor Lagoon, SE Spain. Fresenius Environmental Bulletin, 13, 274-278.

Barceló, J., \& Poschenrieder, C. (1992). Respuestas de las plantas a la contaminación por metales pesados. Suelo y Planta, 2, 345-361.

Belchí, J., Moreno, S., Bayo, J., Rosique, C., Batolomé, B., \& Moreno, J. M. (1997). Zygophyllum fabago L.: A new source of allergenic pollen. Journal of Allergy and Clinical Immunology, 99, 493-496.

Cobb, G. P., Sands, K., Waters, M., Wixson, B. G., \& DorwardKing, E. (2000). Accumulation of heavy metals by vegetables grown in mine wastes. Environmental Toxicology and Chemistry, 19, 600-607.

Conesa, H. M., Faz, Á., García, G., Arnaldos, R., \& Llona, M. (2003). Recuperación y/o estabilización de los terrenos mineros de La Unión-Cartagena (Murcia) mediante la revegetación con especies mediterráneas. In I. Rábano, J. I. Manteca, \& C. García (Eds.), Patrimonio geológico y minero y desarrollo regional (pp. 315-320). Madrid, Spain: Instituto Geológico y Minero de España.

Conesa, H. M. (2005). Restoration/stabilization of heavy metal polluted soils due to mining activities in Cartagena-La Unión Mining District. Universidad Politécnica de Cartagena, Cartagena, Spain. PhD thesis.

Conesa, H. M., Faz, Á., \& Arnaldos, R. (2006). Heavy metal accumulation and tolerance in plants from mine tailings of the semiarid Cartagena-La Unión mining district (SE Spain). Science of the Total Environment, $366,1-11$.

Conesa, H. M., Nowack, B., Robinson, B. H., \& Schulin, R. (2007). Growth of Lygeum spartum in acid mine tailings: Response of plants developed from seedlings, rhizomes and at field conditions. Environmental Pollution, 145, 700-707.

Davison, J., \& Wargo, M. (2001). Syrian beancaper: Another new noxious weed threatens Nevada. Cooperative extension, FS-01-46. University of Nevada, Reno, USA. Retrieved July 1, 2006, from http://www.unce.unr.edu/ publications/FS01/FS0146.pdf.

Diaz, G., \& Honrubia, M. (1993). Respuestas de crecimiento del albardín (Lygeum spartum L.) a la inoculación con hongos micorrícicos y a la fertilización fosforada. Cryptogamie Mycologie, 14, 117-125.

Dudka, S., \& Adriano, D. C. (1997). Environmental impacts of metal ore mining and processing: A review. Journal of Environmental Quality, 26, 590-602. 
Fitz, W. J., \& Wenzel, W. W. (2002). As transformations in the soil-rhizosphere-plant system: Fundamentals and potential application to phytoremediation. Journal of Biotechnology, 99, 259-278.

Flores-Tavizón, E., Alarcón-Herrera, M. T., GonzálezElizondo, S., \& Olguín, E. J. (2003). As tolerating plants from mine sites and hot springs in the semi-arid Region of Chihuahua, Mexico. Acta Biotechnologica, 23, 113-119.

García, G., Faz, Á., \& Conesa, H. M. (2003). Selection of autochthonous plant species from SE Spain for soil $\mathrm{Pb}$ phytoremediation purposes. Water, Air, and Soil Pollution Focus, 3, 243-250.

García, G., Faz, Á., \& Cunha, M. (2004a). Performance of Piptatherum miliaceum (Smilo grass) in edaphic $\mathrm{Pb}$ and $\mathrm{Zn}$ phytoremediation over a short growth period. International Biodeterioration \& Biodegradation, 54, 245-250.

García, G., Sánchez-Cervantes, A., \& Faz, Á. (2004b). Reclamation of heavy metal polluted soils by Zygophyllum fabago. Effect of time on accumulation rate. In Á. Faz, R. Ortiz, \& G. García (Eds.), Extended abstracts of the ICLD4 (Fourth Intertanional Conference on Land Degradation). Murcia, Spain: Cartagena.

Henriques, F. S., \& Fernandes, J. C. (1991). Metal uptake and distribution in rush (Juncus conglomeratus L.) plants growing in pyrites mine tailings at Lousal, Portugal. Science of the Total Environment, 102, 253-260.

IGME (Instituto Geominero de España). (1999). Inventario Nacional de Balsas y Escombreras de la Región de Murcia. Madrid, Spain. Technical report.

Leita, L., De Nobili, M., Pardini, G., Ferrari, F., \& Sequi, P. (1989). Anomalous contents of heavy metals in soils and vegetation of a mine area in S. W. Sardinia, Italy. Water, Air and Soil Pollution, 48, 423-433.

Macnair, M. R. (1987). Heavy metal tolerance in plants: A model evolutionary system. Trends in Ecology and Evolution, 2, 354-359.

Martínez-Orozco, J. M., Valero-Huete, F., \& Gónzalez-Alonso, S. (1993). Environmental problems and proposals to reclaim the areas affected by mining exploitations in the Cartagena mountains (southeast Spain). Landscape and Urban Planning, 23, 195-207.

Martos-Miralles, P., Sansano-Sánchez, A., Baños-Páez, P., Navarro-Cano, J. A., \& Méndez-Pérez, T. (2001). Medio Ambiente y Empleo en la Sierra Minera de Cartagena-La Unión. La Unión, Murcia, Spain: Fundación Sierra Minera.

Mattina, M. I., Lannucci-Berger, W., Musante, C., \& White, J. C. (2003). Concurrent plant uptake of heavy metals and persistent organic pollutants from soil. Environmental Pollution, 124, 375-378.

McGrath, S. P., \& Zhao. F.-J. (2003). Phytoextraction of metals and metalloids from contaminated soils. Current Opinion in Biotechnology, 14, 277-282.
Melendo, M., Benítez, E., \& Nogales, R. (2002). Assessment of the feasibility of endogeneous Mediterranean species for phytoremediation of $\mathrm{Pb}$-contaminated areas. Fresenius Environmental Bulletin, 11, 1105-1109.

Norland, M. R., \& Veith, D. L. (1995). Revegetation of coarse taconite iron ore tailing using municipal waste compost. Journal of Harzardous Materials, 41, 123-134.

Oen, I. S., Fernández, J. C., \& Manteca, J. I. (1975). The leadzinc and associated ores of La Unión, Sierra de Cartagena, Spain. Economic Geology, 70, 1259-1278.

Ortega, M., Nicolás, E., Esteve, M. A., Torres, A., \& Ramírez-Díaz, L. (1993). Prioridades en la restauración e integración paisajística de la Sierra Minera de La Unión y Cartagena (Murcia, Sureste de España): Inventario, cartografía y tipología de cortas, balsas y escombreras. In R. Ortiz-Silla (Ed.), Problemática ambiental y desarrollo (pp. 307-316). Murcia, Spain: Sociedad Española de Geología Ambiental y Ordenación del Territorio.

Robinson, B. H., Leblanc, M., Petit, D., Brooks, R. R., Kirkman, J. H., \& Gregg, P. E. H. (1998). The potential of Thlaspi caerulescens for phytoremediation of contaminated soils. Plant and Soil, 203, 47-56.

SYSTAT. (2002). Version 10.2 Systat Software Inc. Richmond, California, USA.

Tordoff, G. M., Baker, A. J. M., \& Willis, A. J. (2000). Current approaches to the revegetation and reclamation of metalliferous wastes. Chemosphere, 41, 219-228.

Tutin, T. G., Heywood, V. H., Burges, N. A., Moore, D. M., Valentine, D. H., Walters, S. M., et al. (1968). Flora Europaea. (Vol II). Cambridge: Cambridge University Press.

USDA (United States Department Agriculture). (2005). Plants Database. Natural Resources Conservation Service. Retrieved January, 2007, from http://plants.usda.gov/java/ noxiousDriver.

Vilar, J. B., Egea-Bruno, P. M., \& Fernández-Gutiérrez, J. C. (1991). La minería murciana contemporánea (1930-1985). Madrid, Spain: Instituto Tecnológico Geominero de España.

Wolfe, A. K., \& Bjornstad, D. J. (2002). Why would anyone object? An exploration of soil aspects of phytoremediation acceptability. Critical Reviews in Plant Sciences, 21, 429-439.

Wong, J. W. C., Ip, C. M., \& Wong, M. H. (1998). Acidforming capacity of $\mathrm{Pb}-\mathrm{Zn}$ mine tailings and its implications for mine rehabilitation. Environmental Geochemistry and Health, 20, 149-155.

Wong, M. H. (2003). Ecological restoration of mine degraded soils, with emphasis on metal contaminated soils. Chemosphere, 50, 775-780.

Ye, Z. H., Wong, J. W. C., Wong, M. H., Baker, A. J. M., Shu, W. S., \& Lan, C. Y. (2000) Revegetation of Pb/Zn Mine Tailings, Guangdong Province, China. Restoration Ecology, 8, 87-92. 